\title{
DAMPAK PROGRAM DANA PEMBERDAYAAN EKONOMI MASYARAKAT DI KECAMATAN OEBOBO KOTA KUPANG
}

\author{
Semarch Dewi Ayu Putri Bida ${ }^{1}$, Nikson Tameno ${ }^{2}$, Novi Theresia Kiak ${ }^{3}$ \\ 1,2,3) Fakultas Ekonomi dan Bisnis Universitas Nusa Cendana \\ Kupang, Indonesia
}

\begin{abstract}
This study examines the Community Economic Empowerment Fund Program, one of the policies to empower people in Kupang City with interest-free funds as capital for developing productive businesses to increase the potential economic community. This study aims to explain the impact of community business development on community empowerment programs by looking at the factors in the delay in returning the program funds and using qualitative descriptive analysis techniques with investigations by interviewing several key informants, including the Chairperson of the LPM, village facilitators, and community recipients of PEM funds. The results showed the implementation of the Community Economic Empowerment Fund program in Oebobo District had a positive impact on increasing community income, community business productivity, community independence, the initial funding roll-out stage from 2013 to 2019 for the community in Oebobo District, Kupang City, and also increasing public awareness of community economic empowerment fund assistance that helps develop community businesses. But on the other hand, there are still arrears caused by several factors, namely lack of understanding from the recipient of the funds, business congestion, absence of financial reports, culture, change of facilitators, and other unexpected things.
\end{abstract}

Keywords $\quad$ : Community independence; Increased revenue; PEM Fund Program

Correspondence to : novi.kiak@staf.undana.ac.id

\begin{abstract}
ABSTRAK
Penelitian ini mengkaji Program Dana Pemberdayaan Ekonomi Masyarakat yang merupakan salah satu kebijakan untuk memberdayaan masyarakat di Kota Kupang dengan bantuan dana tanpa bunga sebagai modal untuk pengembangan usaha produktif demi meningkatkan potensi perekonomian masyarakat. Penelitian ini bertujuan untuk menjelaskan dampak pengembangan usaha masyarakat dengan adanya program pemberdayaan masyarakat dengan melihat faktor- faktor terjadinya keterlambatan pengembalian dana program tersebut. Dengan menggunakkan teknik analisis deskriptip kualitatif dengan investigasi mewawancarai beberapa informan kunci, meliputi Ketua LPM, fasilitator kelurahan selaku tenaga pendamping serta masyarakat penerima dana PEM. Hasil penelitian menunjukkan bahwa Pelaksanaan program Dana Pemberdayaan Ekonomi Masyarakat di Kecamatan Oebobo menghasilkan dampak positif meningkatkan pendapatan masyarakat, produktivitas usaha masyarakat, kemandirian masyarakat, tahap pengguliran dana tahap awal dari tahun 2013 hingga 2019 bagi masyarakat di Kecamatan Oebobo Kota Kupang dan juga peningkatan kesadaran masyarakat terhadap bantuan dana pemberdayaan ekonomi masyarakat
\end{abstract}


yang membantu pengembangan usaha masyarakat. Namun disisi lain masih terdapat tunggakan yang disebabkan oleh beberapa faktor yaitu kurang ada pemahaman dari penerima dana , kemacetan usaha, tidak adanya laporan keuangan, budaya, pergantian fasilitator dan hal tak terduga lainnya.

Kata Kunci: Kemandirian masyarakat; Peningkatan Pendapatan; Program Dana PEM

\section{PENDAHULUAN}

Provinsi Nusa Tenggara Timur (NTT) yang beribukota Kupang menghadapi persoalan tingkat kesejahteraan masyarakat yang cukup kompleks, dimana jumlah penduduk miskin di Kota Kupang pada tahun 2012 memiliki presentase sebesar 9,58\%, kemudian mengalami penurunan sampai tahun 2014 menjadi 8,76\%. Namun di tahun 2015 mengalami kenaikan sebesar 10,16\%. Pemerintah Kota Kupang melaksanakan pemberdayaan ekonomi masyarakat melalui bantuan dana bergulir yang dikenal dengan Dana Pemberdayaan Ekonomi Masyarkat (PEM), dalam rangka meningkatkan taraf hidup masyarakat, khususnya masyarakat yang berpenghasilan rendah. Program ini memberikan dana untuk pengembangan usaha ekonomi produktif dan harus dikembalikan kepada kas Lembaga Pemberdayaan Masyarakat (LPM) yang kemudian akan diberikan kembali ke masyarakat. Program Dana PEM di Kecamatan Oebobo, menunjukkan bahwa meskipun kelurahan-kelurahan tersebut mendapatkan bantuan program PEM sampai saat ini, tetapi perkembangan program kegiatan pada masing-masing kelurahan berbeda satu sama lain.

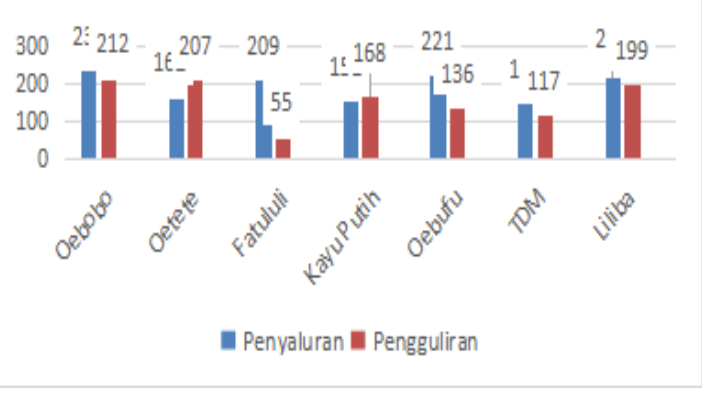

Gambar. 1

Jumlah Penerima Dana

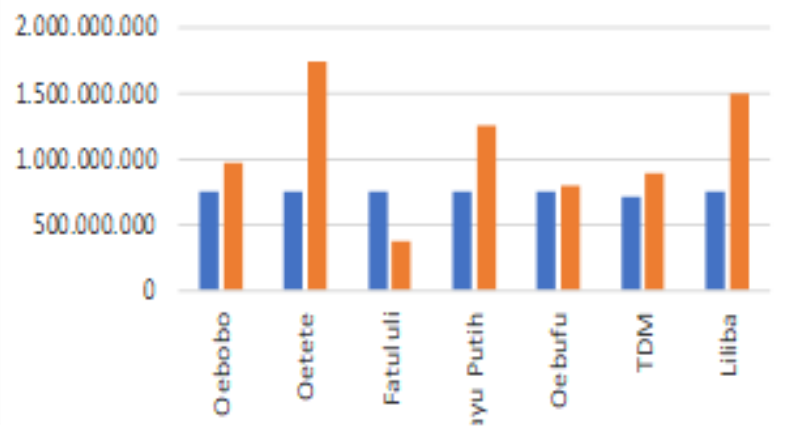

Gambar. 2

Jumlah Dana Yang Disalurkan

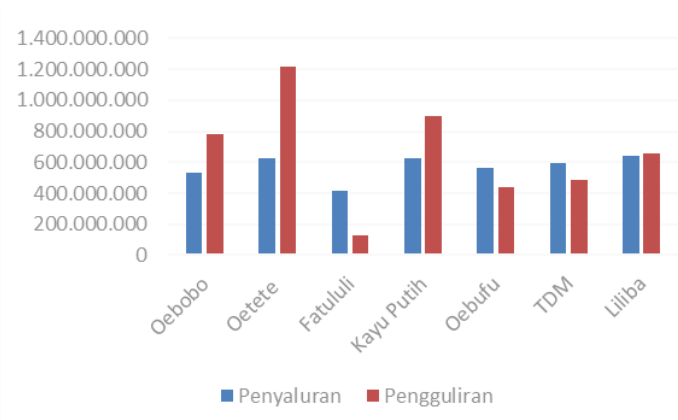

Gambar. 3

Pengembalian Dana 
Sumber: Badan Perencanaan Pembangunan Daerah (BAPPEDA) Kota Kupang, 2019 (Data diolah)

Penyaluran dana PEM mempunyai alokasi yang merata di semua kelurahan. Dari pengalokasian yang merata, terdapat kelurahan yang unggul dalam pelaksanaan program ini, seperti kelurahan Oetete dengan jumlah penerima dana yang meningkat dan juga jumlah pengguliran dana terbesar yaitu Rp 1.731.500.000 diikuti dengan kelurahan Kayu putih dengan jumlah pengguliran dana sebesar Rp 1.247.500.000. Meskipun begitu, masih terdapat kelurahan yang belum mampu melaksanakan program ini dengan baik misalnya masalah tunggakan berkaitan dengan usaha untuk meningkatkan produktifitas masyarakat dan bagaimana usaha produktufitas masyarakat. Permasalahan Program Dana Pemberdayaan Ekonomi Masyarakat (PEM) di Kecamatan Oebobo, Kota Kupang, menimbulkan pertanyaan apakah program PEM ini telah berjalan optimal, dan bagaimana dampak yang diperoleh dari program PEM, serta faktor-faktor apa saja yang mempengaruhi terjadinya keterlambatan dalam pengembalian dana program PEM di Kecamatan Oebobo, Kota Kupang.

\section{METODE PENELITIAN}

\section{Jenis dan pendekatan Penelitian}

Penelitian ini menggunakan

pendekatan survey, sedangkan jenis penelitian yang digunakan adalah penelitian deskriptif kualitatif.

\section{Jenis dan Teknik Pengumpulan Data} Jenis Data terdiri dari Data Kuantitatif yang berupa jumlah penerima dana PEM 1 dan jumlah dana PEM yang disalurkan. Serta Data Kualitatif yang berupa nama penerima dana PEM, jenis usaha dan alamat obyek penelitian. Teknik Pengumpulan Data yang digunakan adalah survey dengan data Primer yang diperoleh langsung dari Ketua Lembaga Pemberdayaan
Masyarakat (LPM) pada setiap Kelurahan di Kecamatan Oeb dan Pelaku usaha penerima Dana PEM di Kecamatan Oebobo melalui wawancara langsung serta Data sekunder yang diperoleh dari Laporan Bulanan rincian Dana Bergulir PEM Kecamatan Oebobo.

\section{Teknik Analisis Data}

Penelitian ini menggunakan analisis kualitatif dengan cara mewawancarai Kepala Desa, wawancara Camat, wawancara pejabat PEM, observasi lapangan dan dokumentasi PEM di Desa. Teknik analisis data yang digunakan setelah memperoleh data diolah dengan menggunakan content analysis. Teknik content analysis merupakan teknik analisa dengan menggunakan kode-kode yang ditemukan dalam sebuah teks perekaman data selama wawancara yang dilakukan dengan subjek di lapangan seperti yang dipaparkan oleh Bungin 2010 bahwa konten analisis memiliki tiga syarat yaitu objektivitas, pendekatan sistematis dan generalisasi. Diawali dengan pemberian kode pada transkip wawancara dimana kode tersebut merupakan kategori yang dikembangkan dari permasalahan penelitian konsep-konsep kunci atau tema-tema penting kemudian kode-kode tersebut menjadi alat yang membantu pengorganisasian data untuk diklasifikasikan. Berikut alur dalam pelaksanaan content analisis :

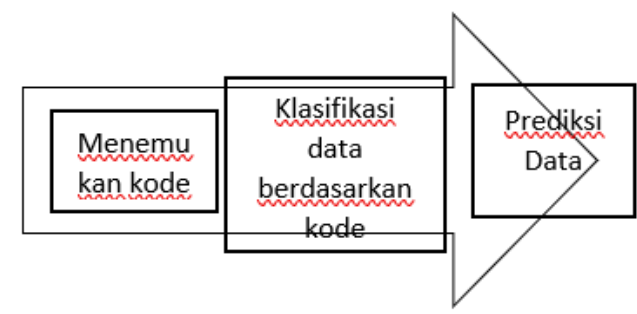

\section{Fokus Penelitian}

Untuk menjelaskan dampak program Dana Pemberdayaan Ekonomi Masyarakat, yang mengacu pada lima dimensi dampak kebijakan menurut Thomasy Day dalam fokus dalam penelitian ini, yaitu:

1. Dampak dari kebijakan pada permasalahan publik serta dampak kebijakan pada peningkatan pendapatan masyarakat.

2. Dampak kebijakan pada peningkatan produktivitas usaha masyarakat. 
3. Dampak kebijakan pada peningkatan kemandirian masyarakat.

4. Dampak kebijakan pada pengguliran dana Pemberdayaan Ekonomi Masyarakat (PEM).

5. Biaya-biaya tidak langsung yang ditanggung oleh masyarakat atau beberapa anggota masyarakat akibat adanya kebijakan publik dengan sub fokus penelitian yaitu peningkatan kesadaran masyarakat terhadap program Dana Pemberdayaan Ekonomi Masyarakat.

\section{HASIL PENELITIAN}

\section{Program Dana Pemberdayaan Ekonomi Masyarakat di Kecamatan Oebobo}

Penyaluran dan pengguliran dana Pemberdayaan Ekonomi Masyarakat (PEM) tahun anggaran yang baru telah dilaksanakan sejak tahun 2013. Terdapat 7 (tujuh) kelurahan penerima Program Dana PEM di Kecamatan Oebobo, yaitu Kelurahan Oebobo, Kelurahan Oetete, Kelurahan Fatululi, Kelurahan Oebufu, Kelurahan Kayu Putih, Kelurahan Tuak Daun Merah (TDM), dan Kelurahan Liliba. Namun, dalam penelitian ini, hanya mengambil 3 (tiga) Kelurahan yang dianggap dapat mewakili Kecamatan Oebobo, yaitu Kelurahan Oetete sebagai kelurahan dengan jumlah penggulirana dana tertinggi, Kelurahan Oebufu sebagai kelurahan dengan jumlah pengguliran dana yang rendah dan Kelurahan Tuak Daun Merah (TDM) sebagai kelurahan dengan presentase pengembalian dana terendah

\section{Analisis Dampak Program Dana Pemberdayaan Ekonomi Masyarakat}

Pelaksanaan program Dana

Pemberdayaan Ekonomi Masyarakat di Kecamatan Oebobo Kota Kupang sejak tahun 2013-2019, memberikan dampak sebagai berikut :

1) Peningkatan Pendapatan Masyarakat

Pelaksanaan Program PEM di Kota

Kupang diharapkan dapat meningkatkan taraf hidup mereka melalui peningkatan pendapatan, sehingga akhirnya mereka bisa memenuhi kebutuhan dalam keluarga dan mendapatkan modal untuk pengembangan usaha mereka.

Menurut hasil penelitian dilapangan, beberapa pelaku usaha di kelurahan Oetete, Kelurahan TDM dan kelurahan Oebufu telah mengalami peningkatan pendapatan setelah mendapat bantuan dana PEM. Dimana menurut mereka, sebelum mendapat bantuan dana PEM, penghasilan penelitian yang telah dilakukan oleh 2 mengenai implementasi bantuan dana bergulir bagi pelaku usaha di Kota Tanjungpinang. Dimana standart dan sasaran yang telah ditetapkan oleh program tersebut pada kenyataannya tidak terealisasi dengan baik dilapangan. Para pelaku usaha yang mendapat bantuan dana tersebut menyalahgunakan dana yang diberikan sehingga tidak berdampak pada usahanya dan tidak terjadi peningkatan pendapatan.

\section{2)Peningkatan Produktivitas Usaha}

Program bantuan dana PEM yang dimulai tahun 2013 hingga sekarang, menunjukkan bahwa produktivitas usaha masyarakat mengalami peningkatan, yang mana awalnya pelaku usaha memiliki jumlah produksi yang rendah dan setelah adanya program dana PEM, masyarakat telah memiliki penambahan jumlah produksi serta menambah jenis usaha lainnya. seperti salah satu usaha milik ibu Agustina di Kelurahan TDM, yang awalnya beliau sebagai penjual kue. Sebelum mendapat bantuan dana PEM, jumlah kue yang dihasilkan per hari sebanyak 50 potong kue, setelah mendapat tambahan modal melalui dana PEM kue yang diproduksi meningkat menjadi 100 potong kue per hari. Usahanya berkembang sampai dia dapat membuka kios sembako dan juga berdagang sayuran, berbeda dengan Hasil penelitian dengan kesimpulan bahwa dari segi prinsip pemberdayaan dengan penambahan modal usaha melalui pendapatan para penerima dana PEM mulai memberdayakan usahanya dengan baik walaupun sebagian besar pendapatan masih digunakan untuk konsumsi. 
3)Peningkatan Kemandirian Masyarakat

Pemberdayaan masyarakat bertujuan untuk membentuk pribadi yang mandiri, baik dalam berfikir dan bertindak, serta mengendalikan apa yang mereka lakukan. Dana PEM merupakan bantuan modal usaha tanpa bunga pinjaman, maka masyarakat harus bisa mengatur dan mengelola dana tersebut sehingga tidak terus-menerus bergantung pada dana PEM.

Berdasarkan hasil wawancara dari 45 informan di tiga kelurahan tersebut, dapat ditarik kesimpulan bahwa terdapat peningkatan kemandirian masyarakat pada 18 pelaku usaha penerima dana PEM dengan persentase $40 \%$ dan masih ada juga pelaku usaha yang belum mandiri sebanyak 27 pelaku usaha dengan persentase $60 \%$, dimana masih bergantung pada bantuan dana PEM tersebut. Dengan melihat hal tersebut, diharapkan agar pemerintah daerah dapat terus menjalankan program dana PEM dengan memberi pendampingan yang cukup agar pelaku usaha yang masih bergantung pada bantuan dana PEM ini dapat terus berusaha untuk mengembangkan usaha mereka sehingga nantinya setelah merasa cukup mampu mengelola usaha yang ada mereka tidak lagi bergantung pada bantuan dana PEM ini dan dapat mandiri.

\section{4)Pengguliran Dana PEM}

Pemberian bantuan dana

Pemberdayaan Ekonomi Masyarakat (PEM) dilaksanakan dalam 2 tahap yaitu tahap penyaluran dan tahap pengguliran. Tahap penyaluran merupakan dana hibah dari Pemerintah Pusat kepada Pemerintah Kota Kupang setiap 2 tahun sekali berupa bantuan yang diberikan kepada kelurahan-kelurahan yang ada di Kota Kupang diantaranya Kelurahan Oetete, Kelurahan TDM dan Kelurahan Oebufu. Sedangkan tahap pengguliran dilakukan ketika dana penyaluran yang diberikan kepada penerima dana PEM telah di setor kembali ke dalam kas LPM dan telah mencapai 25\%, maka dapat dilakukan pengguliran. Apabila penerima dana PEM sudah melunasi tepat waktu atau dalam jangka waktu 18 bulan, maka mereka diberikan kesempatan untuk mendapatkan pengguliran dana pada periode berikutnya. Batas maksimal bantuan yang diberikan adalah sebesar Rp 25.000.000 per pelaku usaha.

5) Peningkatan Kesadaran Masyarakat

Sebagian masyarakat cukup sadar terhadap program Dana PEM ini, hal tersebut dibuktikan dengan makin berkembangnya usaha dan meningkatnya pendapatan usaha mereka. Dengan melihat perkembangan yang ada, maka makin banyak masyarakat yang merespon baik terhadap bantuan dana PEM dan membuat pelaku usaha lainnya juga ingin untuk mendapatkan bantuan dana PEM ini.

Namun ada juga beberapa penerima dana PEM yang belum menyadari akan program ini. Mereka masih menganggap bahwa program dana Pemberdayaan Ekonomi Masyarakat ini merupakan bantuan yang diberikan secara gratis kepada mereka tanpa harus dikembalikan, sehingga masih ada penerima dana yang setelah diberi haknya untuk mendapatkan bantuan pinjaman namun tidak menjalankan kewajibannya untuk membayar kembali pinjaman tersebut.

Faktor - Faktor yang mempengaruhi terjadinya keterlambatan pengembalian dana Pemberdayaan Ekonomi Masyarakat (PEM)

Prinsip program Pemberdayaan Ekonomi Masyarakat Kota Kupang ialah penguatan modal usaha dalam bentuk dana bergulir tanpa bunga. Namun, pada pelaksanaan Program dana PEM di Kelurahan Oetete, Kelurahan TDM dan Kelurahan Oebufu masih juga terjadi penunggakan dalam jumlah yang besar. Hal ini dipengaruhi oleh beberapa faktor:

1. Kemacetan usaha, merupakan alasan yang sering digunakan para pelaku usaha yang terlambat dalam pengembalian pinjaman. Hal ini didasarkan karena adanya persaingan dimana munculnya pelaku usaha baru yang serupa di lingkungan tempat usaha mereka sehingga para konsumen mulai terbagi dan membuat pendapatan mereka 
berkurang. Akibatnya pendapatan hanya cukup dibelanjakan untuk modal usaha saja, dan tidak cukup untuk membayar cicilan pinjaman sehingga terpaksa harus menunggak.

2. Kurangnya pemahaman masyarakat dalam memahami bantuan dana PEM membuat masyarakat menganggap bahwa dana yang diberikan ini merupakan dana bantuan dari pemerintah yang tidak harus dikembalikan, sehingga tidak ada kewajiban untuk melunasi kembali dimana setelah menerima bantuan tersebut, para pelaku usaha tidak menjalankan kewajiban mereka untuk mengembangkan dana bantun yang telah diterima, tetapi merek justru menghilang sehingga dana tersebut tidak kembali dan tidak dapat untuk digulirkan.

3. Kurangnya Manajemen Akuntansi. Sebagian penerima dana PEM tidak membuat pembukuan terhadap usaha mereka sehingga mereka tidak tau berapa pemasukan maupun pengeluaran disetiap bulannya. Akibat manajemen keuangan yang kurang baik maka dana tersebut jadi terbagi dengan keperluan lain bukan hanya untuk pengembangan usaha saja sehingga usaha mereka tidak berkembang dan tidak bisa membayar cicilan.

4. Faktor Budaya. Masyarakat Nusa Tenggara Timur (NTT) merupakan masyarakat yang masih kental dengan kebudayaan serta memegang erat adat istiadatnya. Faktor kebudayaan yang dimaksud ialah dimana sebagian besar masyarakat menggunakan pendapatan dan tabungan mereka untuk keperluan adat seperti kumpul keluarga (pernikahan,kematian, maupun acara lainnya) sehingga uang yang harusnya dipakai untuk membayar cicilan terpaksa harus digunakan untuk membiayai keperluan adat tersebut dan pelaku usaha akhirnya menunggak dalam pengembalian pinjaman.

5. Membayar Pendidikan Anak. Jumlah tanggungan anak dalam keluarga menjadi salah satu faktor terjadinya keterlambatan dalam pengembalian pinjaman dimana orang tua harus membiayai keperluan dari anak-anaknya.

6. Hal tak terduga lainnya. Yang dimaksud disini adalah hal-hal seperti penerima dana mengalami bencana seperti kebakaran atas usaha dan/atau tempat tinggal dari penerima dana PEM, maupun bencana alam lainnya yang menimpa usaha dan/atau tempat tinggal dari penerima dana PEM, serta penerima dana yang telah meninggal dunia sehingga tidak dapat membayar cicilan.

7. Pergantian Fasilitator Kelurahan, dimana fasilitator yang baru sering tidak mau mengurus masalah dimasa jabatan sebelumnya, sehingga permasalahan tunggakan ditahun sebelumnya tidak teratasi dan dapat menyebabkan ketidaklancaran dalam pelaksanaan dana PEM.

\section{KESIMPULAN}

Kebijakan Program Dana Pemberdayaan Ekonomi Masyarakat tahun anggaran baru yang telah berlangsung sejak tahun 2013 di Kota Kupang sudah berjalan dengan baik di Kecamatan Oebobo, Kota Kupang dan ditemukan dampak: terjadi Peningkatan pendapatan masyarakat pelaku usaha setelah mendapat bantuan dana PEM, peningkatan produktivitas usaha masyarakat, peningkatan kemandirian masyarakat, Pengguliran Dana PEM yaitu masyarakat mendapatkan kesempatan untuk memperoleh bantuan pada tahap penyaluran dan pengguliran, serta Peningkatan kesadaran masyarakat. Namun dalam pelaksanaanya masih juga terdapat pelaku usaha penerima dana PEM yang belum dapat memanfaatkan dana ini dengan baik sehingga masyarakat mengalami ketidakalncaran, ketidaktepatan waktu dan macet dalam pengembalian pinjaman hal ini karena kurangnya peran fasilitator sebagai tenaga pendamping. Adapun faktor-faktor yang mempengaruhi terjadinya keterlambatan dalam pengembalian pinjaman, antara lain: Kemacetan usaha, kurangnya pemahaman masyarakat tentang dana PEM, dimana masih ada beberapa pelaku usaha yang mengganggap dana ini seperti dana bantuan sosial yang tidak harus dikembalikan, Kurangnya manajemen 
Akuntansi yaitu beberapa pelaku usaha belum mampu membuat manajemen keuangan yang baik atas usaha mereka. Hal - hal tak terduga lainnya, seperti bencana atau musibah yang membuat mereka mengalami kebangkuratan usaha, serta pergantian Fasilitator/tenaga pendamping dimana fasilitator yang baru sering tidak mau mengurus masalah dimasa jabatan sebelumnya, sehingga permasalahan tunggakan ditahun sebelumnya tidak teratasi dan dapat menyebabkan ketidaklancaran dalam pelaksanaan dana PEM.

\section{DAFTAR PUSTAKA}

Asmara, Chintya Fibri, 'IMPLEMENTASI BANTUAN DANA BERGULIR BAGI PELAKU USAHA ( Studi Kasus Dinas Tenaga Kerja , Koperasi Dan Usaha Mikro Kota Tanjungpinang )', Naskah Publikasi, 2018, 1-18

M, Kiu. Y., 'Evaluasi Dampak Program Dana Pemberdayaan Ekonomi Masyarakat Di Kelurahan Kayu Putih Kota Kupang', Jurnal Analisis Kebijakan Dan Pelayanan Publik, 4 (2018), 113

Patrick, Ronald, and Costantin Fanggidae, 'Dampak Implementasi Dana Pemberdayaan Ekonomi Masyarakat Terhadap Peningkatan Masyarakat', Jurnal Ilmu Ekonomi, 2013, 1-17

Bungin Burhan, 'Metodologi Penelitian Kualitatif: Aktualisasi Metodologi Ke
Arah Ragam Varian Kontemporer', in Metodologi Penelitian Kualitatif Aktualisasi Metodologis Ke Arah Ragam Varian Kontemporer, 2019, p. 303

Milles, Huberman, 'Analisis Data Kualitatif', in Analisis Data Kualitatif, 1992

Muhafidin, H. D., SIP, M. S., Yadiman, H., \& SH, M. (2020). Dimensi Kebijakan Publik: Edisi Revisi. Penerbit Andi.

Indonesia, R. (2004). Undang Undang No. 33 Tahun 2004 tentang Perimbangan Keuangan Pemerintah Pusat dan Daerah. Jakarta: available online at www. bpkp. go. id.

Indonesia, U. U. N. (2007). Peraturan Pemerintah Nomor 38 Tahun 2007 tentang Pembagian Urusan Pemerintahan Antara Pemerintah. Pemerintahan Daerah Provinsi dan Pemerintahan Daerah Kabupaten/Kota.

Peraturan Daerah Nomor 10 Tahun 2008 tentang Pengelolaan Dana Pemberdayaan Ekonomi Masyarakat

Keputusan Walikota Kupang Nomor 112 D/KEP/HK/2017 tentang Perubahan atas Keputusan Walikota Kupang No. 15A/Kep/HK/2013 tentang

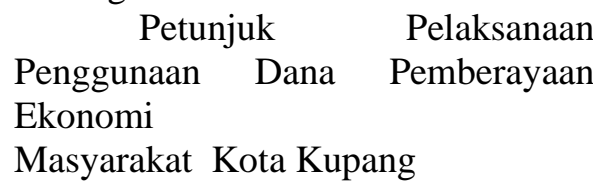

